\title{
Regional-scale relationship among biological soil crusts, invasive annual grasses, and disturbance
}

\author{
Eric B Peterson ${ }^{1,2}$
}

\begin{abstract}
Introduction: Sagebrush ecosystems in western North America are being replaced by the invasion of annual grasses, particularly Bromus tectorum. In experimental situations and in localized landscapes, prior studies have documented that biological soil crusts (biocrusts) can reduce annual grass presence and that biocrusts are highly vulnerable to physical disturbance. Practical conservation would benefit from verification of these patterns at scales that matter to local economies. This study tests if these patterns appear at a regional scale.
\end{abstract}

Methods: A previously collected data set of vegetation provided sampling of biocrust cover across the Great Basin within the state of Nevada, USA. Data were analyzed with non-parametric methods including odds ratios and generalized additive models (GAM).

Results: From a data set of 608 vegetation plots within the Great Basin ecoregion, proportion of plots with high annual grass cover differed between sites with high versus low biocrust cover $(p=0.0015)$. A negative relationship between annual grass cover and biocrust cover was confirmed with GAM $(p=0.009)$. For a model of biocrust cover, cattle disturbance was found to be an explanatory variable $(p<0.00001)$.

Conclusions: The patterns do appear at the regional scale, with high levels of cattle activity corresponding to low cover of biocrusts, and low cover of biocrusts corresponding to high cover of annual grasses.

Keywords: Biological soil crusts, Cryptogamic crust, Microphytic crust, Great basin ecoregion, Sagebrush ecosystem, Landscape ecology, Disturbance, Cattle grazing, Odds ratio, Generalized additive models

\section{Introduction}

The intermountain west of North America is an arid region that was once dominated by shrubs, particularly Artemisia spp. (sagebrushes), with perennial bunchgrasses. In recent decades, invasion by exotic annual grasses, particularly Bromus tectorum (cheatgrass), has not only altered the herbaceous component of the vegetation but is entirely replacing the natural shrub-dominated ecosystems that historically dominated this vast area (Young and Evans 1973; D'Antonio and Vitousek 1992; Pellant 1996; Chambers et al. 2007). What once was called the "Sagebrush Ocean" (Trimble 1999) is fast becoming the "Cheatgrass Sea."

Biological soil crusts (hereafter "biocrusts") are known to be a key component of arid ecosystems (Belnap et al.

\footnotetext{
Correspondence: ebpeterson@usbr.gov

${ }^{1}$ Nevada Natural Heritage Program, State of Nevada, Carson City, NV 89701, USA

${ }^{2}$ Current Address: Trinity River Restoration Program, U.S. Bureau of Reclamation, Weaverville, CA 96093, USA
}

2001a). Experimental studies have shown that biocrusts inhibit invasion of annual grasses (Belnap et al. 2001b; Serpe et al. 2006; Deines et al. 2007). However, physical disturbances, including trampling, damage delicate biocrusts, and recovery is slow (Belnap et al. 2001a; Warren and Eldridge 2001). Inferred causal relationships have been supported correlatively in localized field situations (Stohlgren et al. 2001; Belnap and Phillips 2001; Ponzetti and McCune 2001; Belnap et al. 2006; Ponzetti et al. 2007). One implication of these studies is that loss of biocrusts in the intermountain west due to widespread disturbance (typically from cattle grazing) enables rapid invasion of annual grasses.

Yet conservation of biocrusts in the intermountain west has been difficult. Effective conservation requires (1) a solid scientific understanding of a situation, (2) practical methods for managing the situation (often referred to as a land manager's "toolbox"), and (3) political willpower to undertake the management. The science of 
biocrusts has advanced greatly in recent decades, as evidenced by this special publication of Ecological Processes, which is devoted to biocrusts, as well as other major publications for both scientists and land managers (Belnap and Lange 2001; Belnap et al. 2001a; McCune and Rosentreter 2007). However, development of management "tools" is still in its infancy, and political will to enact management tools is largely absent. The primary management tool available at present is the reduction of cattle grazing. While the argument can be made that better land management provides more sustained economic yield as well as reduced risk of wildfire, employing this tool in areas where grazing is vital to rural economies is politically almost impossible. Furthermore, initial impacts to biocrusts over much of the intermountain west may have happened over a century ago, well before annual grasses invaded, making it difficult for current generations of ranchers to understand the importance of biocrusts. This temporal disconnection allows for questioning of the relevance of localized studies to other grazed rangelands. Biocrust conservation cannot become successful without improvements to science-based land-management tools as well as clarification of the relevance of biocrusts to the broader rangelands that support rural communities.

This study examines how the disturbance-biocrustannual grass relationships manifest at a regional scale. To study biocrusts at this scale, a data set that was collected for vegetation description and remote sensing (the $\mathrm{NeVeg}$ dataset) is utilized to examine two hypotheses about biocrusts at an ecoregional scale:

Hypothesis A: Annual grasses are negatively correlated with biocrusts at the ecoregional scale of the Great Basin.

Hypothesis B: Biocrusts are negatively correlated with disturbance agents at the ecoregional scale of the Great Basin.

Validation of these hypotheses could strengthen the foundation of political support for biocrust conservation because it would demonstrate that high levels of disturbance correspond to low biocrust cover and that low biocrust cover corresponds to high cover of invasive annual grasses at a scale that spans Great Basin rangelands.

\section{Methods}

\section{Study area}

Biocrusts are examined across the Great Basin ecoregion (Bryce et al. 2003) within the state of Nevada, USA. The Great Basin is defined by cool-deserts and block-faulted basin-and-range geology with primarily andesitic rock types. Elevation ranges from about 1,000 to over 3,500 m. Precipitation falls mainly from November through May, often as snow, with average annual precipitation at lower elevations ranging from approximately 7 to $35 \mathrm{~cm}$, and exceeding $100 \mathrm{~cm}$ at high elevations. The native vegetation is composed primarily of shrubs (especially Artemisia spp., Atriplex spp., and Sarcobatus spp.) and small coniferous trees (Pinus monophylla and Juniperus osteosperma), with an understory of grasses, forbs, and biocrusts. Taller conifers and Populus tremuloides are mostly restricted to high elevation montane habitats.

The Great Basin is distinguished from the Mojave Desert to the south, which is a hot-desert; the Columbia Plateau to the north, which is somewhat less arid, generally flatter, and dominated by geologically recent basalt flows; and the Sierra Nevada mountains to the west, with a wetter, more coastal climate. The Great Basin extends eastward into the state of Utah beyond the study area, ending at the Wasatch Mountains and Colorado Plateau, which have different geologies and stronger monsoonal weather patterns.

\section{Sampling}

From 2002 through 2006, 1,217 vegetation plots were sampled by the Nevada Natural Heritage Program on public lands (often grazed) throughout the state of Nevada and neighboring areas for two purposes: (1) developing methods for mapping annual grasses from remotely sensed satellite imagery (Peterson 2005, 2007, $2008 \mathrm{~b}$ ), and (2) describing the vegetation communities of Nevada (Peterson 2008a), including consideration of biocrusts. For this study, these data (the NeVeg dataset) were limited to plots within the Great Basin ecoregion as defined by Bryce et al. (2003), which also limited data to plots sampled from 2002 through 2005.

Plots were primarily 0.1 ha circular areas, although some smaller plots of unusual vegetation types were included. Plots were opportunistically located throughout the area of mapping (Figure 1) to develop statistical relationships for estimating annual grass cover from a combination of satellite-based spectral radiometry and geospatial ecological gradients (e.g., topography and climate variables such as precipitation and temperature). Invasion of annual grasses in the Great Basin has mainly occurred at lower elevations, so high elevation sites are poorly represented by the data set; furthermore, focus on annual grass cover resulted in a disproportionate sampling of heavily invaded sites.

Vegetation sampling was by ocular estimation of total groundcover across the whole plot, which corresponds to methods commonly used for vegetation classification and mapping in western North America (Lowry et al. 2007; Sawyer et al. 2009). Estimations were made for each species of vascular plant, while a single estimation was made for all biocrusts because analysis of biocrust community structure was not a driving purpose of the sampling. Biocrusts were typically dominated by lichens and mosses; cover estimates probably underdetected the presence of cyanobacteria, as time limitations allowed 


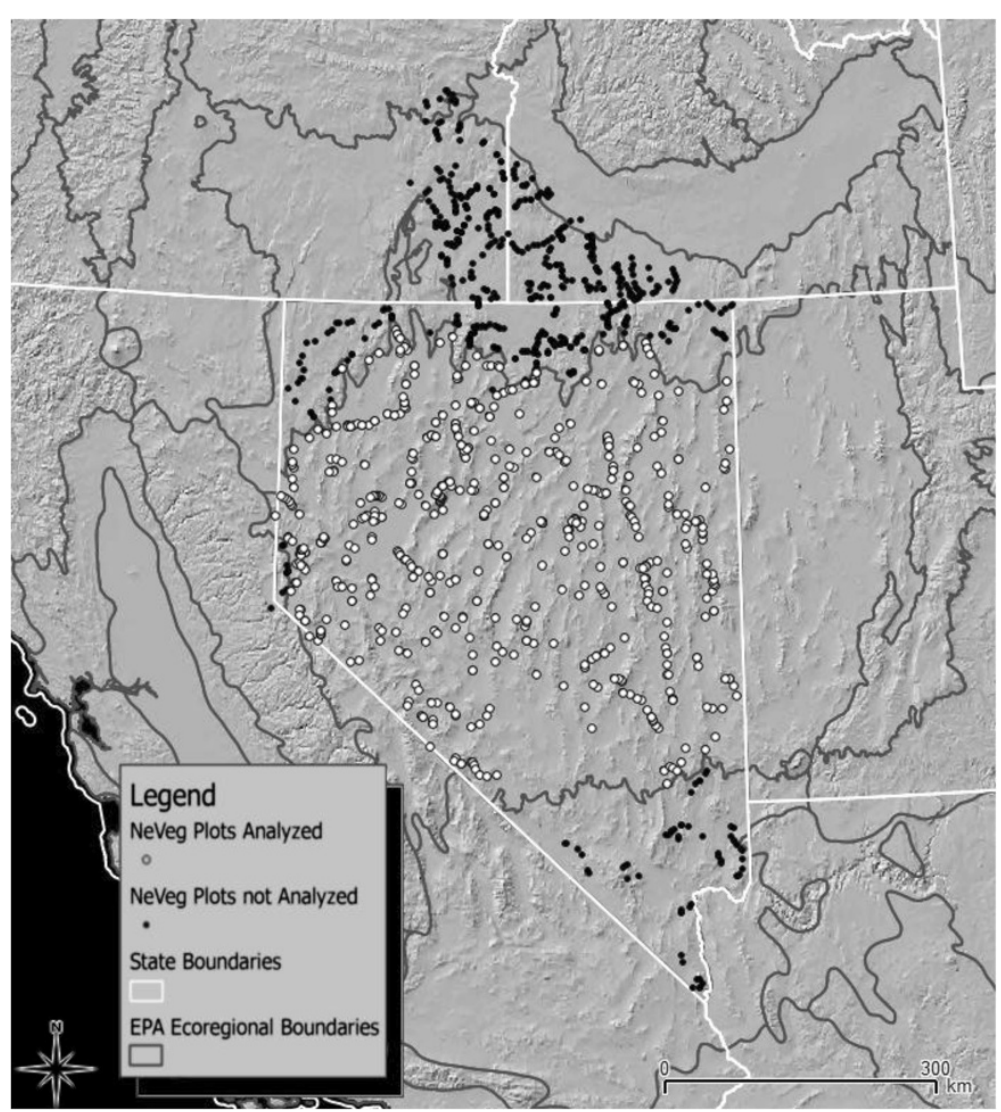

Figure 1 Sampling locations in the state of Nevada, USA, and neighboring states. Large circles are plots retained for analysis; small black dots show additional vegetation plots available. Black lines traversing the state separate the Great Basin ecoregion from the Columbia Plateau to the north and the Mojave Desert to the south.

their inclusion only when their abundance was sufficient to visibly alter the soil surface texture. Further details of plot sampling are given by Peterson $(2005,2006)$.

\section{Analysis}

Percent groundcover values range from 0 to 100 and cannot be negative. Thus data are left-censored at 0 and tend to be strongly skewed. Prior work with these data for developing remotely sensed maps of annual grass cover (Peterson 2005, 2008a, 2008b) used survival analysis to analyze these distributions, but in that case, only the response variable was censored. In this study, both annual grass groundcover and biocrust cover are censored. Further complicating statistical analysis, the ecoregional scope of this study yielded many plots where both annual grasses and biocrusts were absent. Therefore non-parametric methods were emphasized.

Hypothesis A was first tested by examining the data for a negative correlation between annual grass groundcover and biocrust groundcover with the Kendall rank correlation coefficient (tau). Due to the large number of plots where both variables were 0 , the hypothesis was also tested using an odds ratio with Fisher's exact test to compare the proportion of plots with high annual grass cover with and without high biocrust cover. Breaks between low and high cover were made based upon the appearance of natural breaks in the data.

Hypothesis A was further examined by searching available ecological variables for alternatives that might drive the observed patterns between biocrusts and annual grasses using generalized additive modeling (GAM). First, singlepredictor models were calculated to assess the strength of each variable as a predictor of annual grass cover. Then a predictor-rich model was used to test if biocrust cover remained statistically significant after maximum variation was accounted for by other available variables. This rich model was developed by starting with a fully saturated model, then stepwise backward selection was used to remove variables that were not statistically significant $(p>0.05)$. Since the purpose of this analysis was not to develop an optimal model for predicting annual grass cover at unknown sites, variable interactions were not examined, and no attempts were made to optimize this model for prediction at additional sites (including over-fitting).

Hypothesis B was also tested using GAM with the same strategy but with biocrusts as the response variable 
and testing if predictors that represent disturbance are statistically significant. Again, interactions were not examined and the model was not optimized for prediction.

In addition to ecological variables collected during vegetation sampling, several variables were obtained from geospatial datasets. Elevation and a topographically calculated heat index (see Peterson 2006) were obtained from the National Elevation Dataset (United States Geological Survey 2005). Climate normals for 1981-2010 for average annual precipitation, average minimum January temperature, and average maximum July temperature, plus the mean dew-point temperature for 2010 were obtained from PRISM data (PRISM Climate Group at Oregon State University 2012).

All statistical analyses were performed in $R$ version 2.15.1 (R Foundation for Statistical Computing 2012). GAM analyses used the MGCV library by Simon Wood, version 1.7-18. Gamma distributions with logarithmic link functions were used for response variables with percent groundcover plus one, thus eliminating zero values. For predictor variables, thin-plate splines were used, initiated with a dimensional basis of two, thus ensuring simple response curves.

\section{Results}

Of the 1,217 vegetation plots available from prior studies, 608 fit the requirement of being located within the Great Basin ecoregion. Across the 608 plots, mean biocrust groundcover was $4.6 \%$ and was highly skewed. Biocrust cover was 0 at 254 plots, trace at 105 , and $1 \%$ or greater at the remaining 249 plots with a maximum groundcover of $75 \%$. Mean groundcover of annual grasses was $9.5 \%$ and was also skewed. Annual grass groundcover was 0 at 208 plots, while 400 plots had 1\% or greater groundcover with a maximum of $98 \%$.

\section{Hypothesis A}

The relationship between biocrust groundcover and annual grass groundcover appears to support an exponentially negative relationship (Figure 2). However, the statistical correlation was low $(\operatorname{tau}=-0.06)$ due to the zero-rich data distribution. Natural thresholds between "low" and "high" levels of groundcover for both biocrusts and annual grasses are visible in Figure 2 at about 20\% ground cover. Defining high as $20 \%$ or greater cover, the proportion of plots with high annual grass cover where biocrust cover is low comes to $106 / 564$, or 0.19 . Meanwhile the proportion where biocrust cover is high comes to $1 / 44$, or 0.02 . The odds of a plot having high cover of annual grasses is much greater if biocrust cover is low than if it is high (one-sided $p=0.0015$ ).

Hypothesis A was further validated through GAM, first by using biocrust cover as a solitary predictor of annual grass cover $(p=0.0001)$ with the model explaining

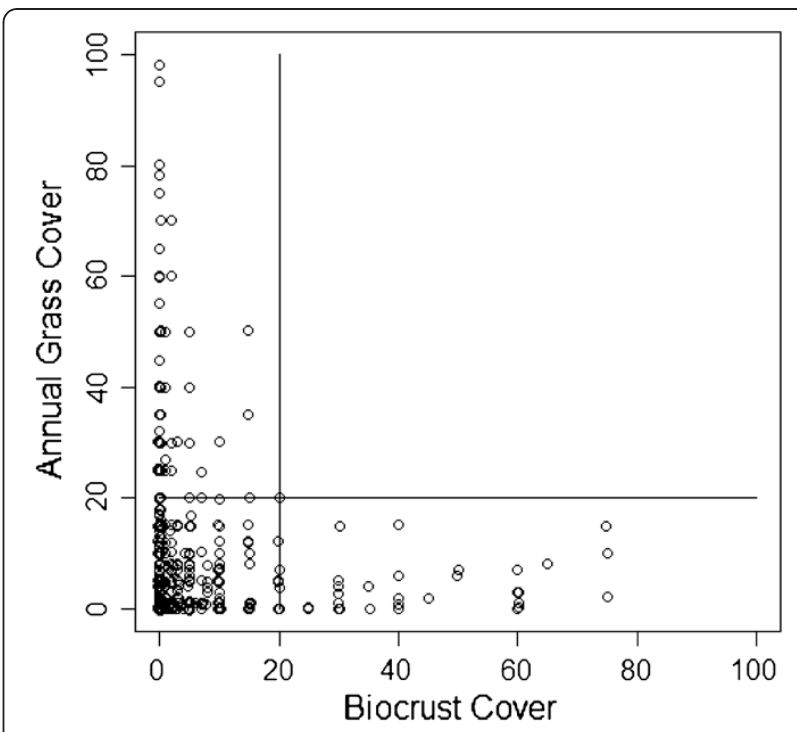

Figure 2 Relationship between biocrusts and annual grasses. Points are jittered slightly to improve visibility of overlapping points. Lines indicate the thresholds between low and high levels of groundcover, used to determine that the proportion of plots with high annual grass cover is significantly greater among plots with low biocrust cover ( $p=0.0015)$.

$3.03 \%$ of deviance, and second by retention of biocrust cover $(p=0.009)$ in the rich model with nine predictors that explained $47.3 \%$ of deviance. Hypothesis A modeling results, including other variables tested, are given in Table 1.

For hypothesis B, disturbance was investigated through a variable that categorizes disturbance by cattle, the primary livestock that graze across the landscape in the Great Basin. Cattle disturbance was ranked based on age and frequency of scat and tracks. Although the NeVeg data set provides multiple measures of disturbance, no others were consistently available for all the plots analyzed in this study. The hypothesis was validated first with cattle disturbance as a solitary predictor of biocrust cover $(p<0.00001)$ with the model explaining $4.72 \%$ of deviance, and second by retention of cattle disturbance $(p<0.00001)$ in the rich model with seven predictors that explained $27.8 \%$ of deviance (Figure 3 ). Hypothesis $\mathrm{B}$ results, including other variables tested, are given in Table 2.

\section{Discussion}

\section{Validation of hypotheses}

This study supports both of the stated hypotheses. Prior experimental studies have indicated a causal inhibition of annual grasses by biocrusts; this study demonstrates that sites with high biocrust cover have low annual grass cover and that biocrust cover is among the predictors of annual grass cover in a model that incorporates other ecological variables. Prior studies have also indicated 
Table 1 GAM model results for the test of Hypothesis $A$

\begin{tabular}{lll}
\hline $\begin{array}{l}\text { Model predictor } \\
\text { variables }\end{array}$ & $\begin{array}{l}\text { Significance of } \\
\text { variable }(\boldsymbol{p})\end{array}$ & $\begin{array}{l}\text { Deviance explained } \\
\text { by model }\end{array}$ \\
\hline Biocrust cover & 0.0001 & $3.03 \%$ \\
\hline Longitude & 0.004 & $1.77 \%$ \\
\hline Latitude & $<0.00001$ & $5.55 \%$ \\
\hline Elevation & $<0.00001$ & $5.50 \%$ \\
\hline Heat index & 0.09 & $0.50 \%$ \\
\hline Mean annual precipitation & $<0.00001$ & $3.05 \%$ \\
\hline $\begin{array}{l}\text { Mean maximum } \\
\text { temperature in July }\end{array}$ & $<0.002$ & $1.77 \%$ \\
\hline $\begin{array}{l}\text { Mean minimum } \\
\text { temperature in January }\end{array}$ & 0.00004 & $3.29 \%$ \\
\hline $\begin{array}{l}\text { Mean temperature of dew } \\
\text { point in 2010 }\end{array}$ & 0.005 & $1.98 \%$ \\
\hline Cattle disturbance ranks & 0.01 & $1.52 \%$ \\
\hline Salt cover & 0.0002 & $1.69 \%$ \\
\hline Rock cover & 0.002 & $1.75 \%$ \\
\hline Bare soil & $<0.00001$ & $26.3 \%$ \\
\hline Biocrust cover & 0.009 & $47.3 \%$ \\
Latitude & 0.001 & \\
Elevation & $<0.00001$ & \\
Mean annual precipitation & $<0.00001$ & \\
Mean minimum & 0.002 & \\
temperature in January & & \\
$\begin{array}{l}\text { Mean temperature of dew } \\
\text { point in 2010 }\end{array}$ & 0.0005 & \\
Cattle disturbance ranks & 0.001 & \\
Rock cover & 0.00001 & \\
Bare soil & $<0.00001$ & \\
\hline & & \\
\hline
\end{tabular}

causal links between disturbance and reduced biocrust cover; this study also demonstrates that disturbance (in this case cattle activity) is among the predictors of biocrust cover in a model that incorporates other ecological variables.

The 20\% threshold analyzed with odds ratios suggests that even moderate levels of biocrust cover (e.g., 20-40\%) may correspond to reduced cover of annual grasses. That said, even $20 \%$ cover of annual grasses may appear as if the land is substantially invaded from the oblique viewpoint of the human eye and may be sufficiently dense to carry wildfire through habitats that otherwise seldom burn (Mensing et al. 2006). Still, the relationship demonstrated here suggests that maintaining (and preferably maximizing) cover of biocrusts could provide a tool for minimizing annual grass invasion in the Great Basin.

GAM results indicate that high cover of annual grasses corresponds to low cover of biocrusts as well as numerous other ecological gradients (Table 1). The most effective predictor analyzed here is the area of bare soil. This variable is partly auto-correlated with annual grasses in that annual

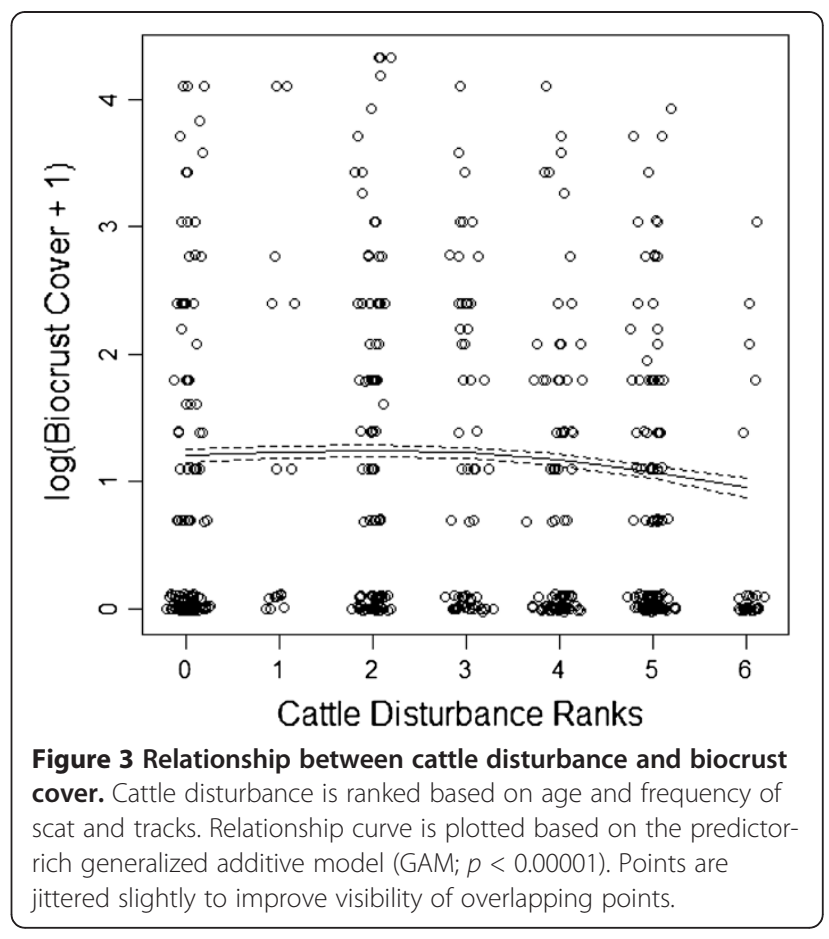

grass cover cannot be bare soil, which may be the reason for the unusually large percent of deviance explained by this variable. Latitude and elevation each account for about $5 \%$ of deviance when used in single-predictor models and are retained in the rich-predictor model. Inclusion of these geospatial variables implies that they represent additional ecological gradients that are not among the available ecological predictor variables. Biocrusts, precipitation, and January minimum temperature each account for about 3\% of deviance in the data.

Biocrust cover is shown by the GAM analyses to correspond to multiple ecological gradients (Table 2). Cattle disturbance ranks are the third strongest predictor among the single-predictor models, behind latitude and elevation. Again, geographic coordinates and elevation account for variation that is not accounted for by available ecological gradients.

The deviance explained by these models may seem small, leading to uncertainty on the effectiveness of controlling cattle disturbance to maximize biocrusts or of maximizing biocrusts to control annual grass invasion. However, the regional scale of this data set spans innumerable gradients, only some of which can be represented here, even with geospatial dimensions included. Of course annual grass cover responds to more than just biocrust cover (e.g., Chong et al. 2006), and of course biocrust cover responds to more than just disturbance by cattle (e.g., Bowker et al. 2007). The degree to which these factors may be used to control each other should be studied at local sites, as they already have been to 
Table 2 GAM results for the test of Hypothesis $B$

\begin{tabular}{lll}
\hline $\begin{array}{l}\text { Model predictor } \\
\text { variables }\end{array}$ & $\begin{array}{l}\text { Significance of } \\
\text { variable }(\boldsymbol{p})\end{array}$ & $\begin{array}{l}\text { Deviance explained } \\
\text { by model }\end{array}$ \\
\hline Longitude & 0.00002 & $2.94 \%$ \\
\hline Latitude & $<0.00001$ & $11.3 \%$ \\
\hline Elevation & $<0.00001$ & $5.54 \%$ \\
\hline Heat index & 0.91 & $0.002 \%$ \\
\hline Mean annual precipitation & $<0.00001$ & $3.95 \%$ \\
\hline $\begin{array}{l}\text { Mean maximum } \\
\text { temperature in July }\end{array}$ & $<0.00001$ & $3.26 \%$ \\
\hline Mean minimum & 0.00004 & $2.18 \%$ \\
temperature in January & & \\
\hline Mean temperature of dew & 0.0003 & $2.63 \%$ \\
point in 2010 & & \\
\hline Cattle disturbance ranks & $<0.00001$ & $4.72 \%$ \\
\hline Salt cover & 0.06 & $0.39 \%$ \\
\hline Rock cover & $<0.00001$ & $3.36 \%$ \\
\hline Bare soil & $<0.00001$ & $2.86 \%$ \\
\hline Longitude & $<0.00001$ & $27.8 \%$ \\
Latitude & $<0.00001$ & \\
Elevation & $<0.00001$ & \\
Mean maximum & 0.00002 & \\
temperature in July & $<0.00001$ & \\
Cattle disturbance ranks & 0.00001 & \\
Rock cover & $<0.00001$ & \\
Bare soil & & \\
\hline
\end{tabular}

some degree. The point of the analysis here is that those local studies are matched by patterns at the regional scale, despite the myriad of ecological gradients.

\section{Annual grass invasion and biocrust conservation}

The scientific understanding of biocrusts and their roles in arid land ecology is strong and improving. Soil crusts are known to inhibit seed germination, including of annual grasses in the intermountain west (Serpe et al. 2006; Deines et al. 2007). These grasses take advantage of openings in the soil-surface niche (Chambers et al. 2007). The strength of the bare soil variable in the annual grass model here further supports this concept of the soil surface niche. Since biocrusts occupy the same niche, we might expect that annual grass invasion could be inhibited when biocrusts occupy a large portion of the soil surface.

Biocrusts are well known to be quite sensitive to physical disturbance of the ground surface by animals including humans, cattle, off-road vehicles, and other agents (Belnap and Eldridge 2001). Feral horses and burros can be a significant disturbance factor in arid lands (Beever et al. 2003) and were frequently observed during $\mathrm{NeVeg}$ sampling, but their effect on biocrusts is not well studied. Feral horses are much more actively mobile than cattle, so even a small number might have a large impact. Timing of disturbance may also be an important factor, as biocrusts might endure more trampling when damp (Belnap and Eldridge 2001; Hilty et al. 2004).

Recovery of biocrusts from disturbance may be less well understood than had originally been presumed; recovery is often said to require hundreds of years. Recovery rates are likely correlated with duration and availability of moisture such that hot, dry deserts may require a century or more to recover from severe disturbances, while cooler, semi-deserts may recover much more quickly (Belnap et al. 2001a). Dojani et al. (2011) found remarkably fast recovery rates, at least for cyanobacteria-dominated crusts and, to a lesser extent, moss-dominated crusts. Belnap et al. (2006) found even lichen-dominated crusts to be highly dynamic across only a few years. When the splined response of biocrusts to cattle in the present study is examined, the curve is essentially flat across the lower ranks of cattle disturbance (Figure 3), suggesting either resistance to, or rapid recovery from, low levels of disturbance. It is possible that much of the loss of biocrusts across the Great Basin landscape was due to historical heavy grazing (Young and Sparks 1985; Freilich et al. 2003) and that current grazing practices are becoming more compatible with biocrust persistence. In a slightly less arid region of the intermountain west, Ponzetti and McCune (2001) observed that while grazing may be detrimental, it may not necessarily be catastrophic to biocrusts. As with other aspects of arid shrubland ecology (see Freilich et al. 2003), examination of different grazing practices relative to biocrust persistence is needed.

\section{Conclusions}

Land managers have many tools for restoring lands already converted from shrublands to annual grasslands, including prescribed fire, herbicides, and seeding or planting of native vascular plants. However, without biocrusts occupying the soil surface niche, resistance of restored areas to reinvasion may be weakened. A few studies have considered methods to restore biocrusts (Jones and Rosentreter 2006; Bowker 2007), but further research on this topic is needed to make widespread biocrust restoration practical. Protection of existing sites is currently the only effective tool available for biocrust management. Uncertainty over the tolerance of biocrusts to disturbance often leads to an assumption that protection requires complete elimination of possible disturbance factors including cattle grazing. Further research on disturbance levels and recovery methods is likely to make biocrusts a more effective tool to help land managers to maintain a diverse landscape and minimize exotic annual grasses.

The biggest challenge to conservation of biocrusts is not science, or even land management tools, but the lack of widespread political will to wield the available tools. 
There are no simple answers on how to improve conservation of biocrusts, and cautious management of grazing is likely key even though it could have local economic impacts. One piece of this puzzle is clarification that biocrusts are important to ecological functions and processes across the landscape. Hopefully this demonstration of regional-level patterns in biocrust disturbance and annual grass invasion will be of help.

\section{Competing interests}

The author declares that there are no competing interests.

\section{Acknowledgements}

Ernie Clarke and Nina Hemphill graciously provided advice and preliminary reviews of the manuscript, while Bruce McCune and an additional anonymous researcher provided formal peer reviews. I thank the staff of the Nevada Natural Heritage Program for various forms of assistance during the collection of the NeVeg dataset, particularly Glenn Clemmer and Jim Morefield who helped guide my work in Nevada, plus Ed Skudlarek and Eric Miskow who helped with significant portions of the fieldwork.

\section{Authorship note}

This study was completed after changing employment. All work on this study (analysis, writing, etc.) was performed outside of the author's activities with the Trinity River Restoration Program and the U.S. Bureau of Reclamation. The views expressed in this study are those of the author and do not reflect those of the Trinity River Restoration Program or the U.S. Bureau of Reclamation.

\section{Received: 19 October 2012 Accepted: 17 January 2013}

Published: 26 February 2013

\section{References}

Beever EA, Tausch RJ, Brussard PF (2003) Characterizing grazing disturbance in semiarid ecosystems across broad scales, using diverse indices. Ecol Appl 13:119-136

Belnap J, Eldridge DJ (2001) Disturbance and recovery of biological soil crusts. In: Belnap J, Lange OL (eds) Biological soil crusts: structure, function, and management, Ecological studies, vol. 150. Springer, New York

Belnap J, Lange OL (2001) Biological soil crusts: structure, function, and management, Ecological studies, vol. 150. Springer, New York

Belnap J, Phillips SL (2001) Soil biota in an ungrazed grassland: response to annual grass (Bromus tectorum) invasion. Ecol Appl 11:1261-1275

Belnap J, Kaltenecker JH, Rosentreter R, Williams J, Leonard S, Eldridge D (2001a) Biological soil crusts: ecology and management. U.S. Bureau of Land Management, Denver

Belnap J, Prasse R, Harper KT (2001b) Influence of biological soil crusts on soil environments and vascular plants. In: Belnap J, Lange OL (eds) Biological soil crusts: structure, function, and management, Ecological studies, vol. 150. Springer, New York

Belnap J, Phillips SL, Troxler T (2006) Soil lichen and moss cover and species richness can be highly dynamic: the effects of invasion by the annual exotic grass Bromus tectorum, precipitation, and temperature on biological soil crusts in SE Utah. Appl Soil Ecol 32:63-76

Bowker MA (2007) Biological soil crust rehabilitation in theory and practice: an underexploited opportunity. Restor Ecol 15:13-23

Bowker MA, Belnap J, Davidson DW, Goldstein H (2007) Correlates of biological soil crust abundance across a continuum of spatial scales: support for a hierarchical conceptual model. J Appl Ecol 43:152-163

Bryce SA, Woods AJ, Morefield JD, Omernik JM, McKay TR, Brackley GK, Hall RK, Higgins DK, McMorran DC, Vargas KE, Peterson EB, Zamudio DC, Comstock JA (2003) Ecoregions of Nevada [color poster with map, descriptive text, summary tables, and photographs]. United States Geological Survey, Reston, VA, USA

Chambers JC, Roundy BA, Blank RR, Meyer SE, Whittaker A (2007) What makes Great Basin sagebrush ecosystems invasible by Bromus tectorum? Ecol Monogr 77:117-145
Chong GW, Otsuki Y, Stohlgren TJ, Guenther D, Evangelista P, Villa C, Waters A (2006) Evaluating plant invasions from both habitat and species perspectives. West N Am Nat 66:92-105

D'Antonio CM, Vitousek PM (1992) Biological invasions by exotic grasses, the grass/fire cycle, and global change. Annu Rev Ecol Syst 23:63-87

Deines L, Rosentreter R, Eldridge DJ, Serpe MD (2007) Germination and seedling establishment of two annual grasses on lichen-dominated biological soil crusts. Plant Soil 295:23-35

Dojani S, Büdel B, Deutschewitz K, Weber B (2011) Rapid succession of biological soil crusts after experimental disturbance in the Succulent Karoo, South Africa. Appl Soil Ecol 48:263-269

Freilich JE, Emlen JM, Duda JJ, Freeman DC, Cafaro PJ (2003) Ecological effects of ranching: a six-point critique. Bioscience 53:759-765

Hilty JH, Eldridge DJ, Rosentreter R, Wicklow-Howard MC, Pellant M (2004) Recovery of biological soil crusts following wildfire in Idaho. J Range Manage 57:89-96

Jones PR, Rosentreter R (2006) Gametophyte fragment growth of three common desert mosses on artificial and natural substrates. Bryologist 109:166-172

Lowry J, Ramsey RD, Thomas K, Schrupp D, Sajwaj T, Kirby J, Waller E, Schrader S, Falzarano S, Langs L, Manis G, Wallace C, Schulz K, Comer P, Pohs K, Rieth W, Velasquez C, Wolk B, Kepner W, Boykin K, O'Brien L, Bradford D, Thompson B, Prior-Magee J (2007) Mapping moderate-scale land-cover over very large geographic areas within a collaborative framework: a case study of the Southwest Regional Gap Analysis Project (SWReGAP). Remote Sens Environ 108:59-73

McCune B, Rosentreter R (2007) Biotic soil crust lichens of the Columbia Basin. Monogr N Am Lichenol 1:1-105

Mensing S, Livingston S, Barker P (2006) Long-term fire history in Great Basin sagebrush reconstructed from macroscopic charcoal in spring sediments, Newark Valley, Nevada. West N Am Nat 66:64-77

Pellant M (1996) Cheatgrass: the invader that won the west. Interior Columbia Basin Ecosystem Management Project, US Bureau of Land Management. Idaho State Office, Boise. http://www.icbemp.gov/science/pellant.pdf

Peterson EB (2005) Estimating cover of an invasive grass (Bromus tectorum) using tobit regression and phenology derived from two dates of Landsat ETM + data. Int J Remote Sens 26:2491-2507

Peterson EB (2006) A map of invasive annual grasses in Nevada derived from multitemporal Landsat 5 TM imagery. Report for the U.S.D.I. Bureau of Land Management. Nevada State Office, Reno, by the Nevada Natural Heritage Program, Carson City, NV

Peterson EB (2007) A map of annual grasses in the Owyhee Uplands, Spring 2006, derived from multitemporal Landsat 5 TM imagery. Report for the U.S. D.I. Bureau of Land Management. Nevada State Office, Reno, by the Nevada Natural Heritage Program, Carson City, NV

Peterson EB (2008a) International vegetation classification alliances and associations occurring in Nevada with proposed additions. Nevada Natural Heritage Program, Carson City, NV

Peterson EB (2008b) Invasion of the exotic grasses: mapping their progression via satellite. In: Kitchen SG, Pendleton RL, Monaco TA, Vernon J (eds) Proceedings - Shrublands under fire: disturbance and recovery in a changing world; 2006 June 6-8, Fort Collins, CO. Proc. RMRS-P-52. U.S. U.S. Department of Agriculture, Forest Service, Rocky Mountain Research Station, Cedar City, UT, pp 33-39

PRISM Climate Group at Oregon State University (2012) 30-arcsec (800 m) Normals (1981-2010). Geospatial climate data. http://www.prism.oregonstate.edu/

Ponzetti JM, McCune B (2001) Biotic soil crusts of Oregon's shrub steppe: community composition in relation to soil chemistry, climate, and livestock activity. Bryologist 104:212-225

Ponzetti JM, McCune B, Pyke DA (2007) Biotic soil crusts in relation to topography, cheatgrass and fire in the Columbia Basin, Washington. Bryologist 110:706-722

R Foundation for Statistical Computing (2012) R version 2.15.1. http://cran.r-project.org/

Sawyer JO, Keeler-Wolf T, Evens JM (2009) A manual of California vegetation, 2nd edn. California Native Plant Society, Sacramento

Serpe MD, Orm JM, Barkes T, Rosentreter R (2006) Germination and seed water status of four grasses on moss-dominated biological soil crusts from arid lands. Plant Ecol 185:163-178

Stohlgren TJ, Otsuki Y, Villa CA, Lee M, Belnap J (2001) Patterns of plant invasions: a case example in native species hotspots and rare habitats. Biol Invasions 3:37-50 
Trimble S (1999) The sagebrush ocean: natural history of the Great Basin (Max C. Fleischmann series in Great Basin natural history). University of Nevada Press, Reno, NV

United States Geological Survey (2005) National Elevation Dataset. http://ned.usgs.gov/

Warren SD, Eldridge DJ (2001) Biological soil crusts and livestock in arid ecosystems: are they compatible? In: Belnap J, Lange OL (eds) Biological soil crusts: structure, function, and management, Ecological studies,

vol. 150. Springer, New York

Young JA, Evans RA (1973) Downy brome-intruder in the plant succession of big sagebrush communities in the Great Basin. J Range Manage 26:410-415 Young JA, Sparks BA (1985) Cattle in the cold desert. University of Nevada Press, Reno, NV

doi:10.1186/2192-1709-2-2

Cite this article as: Peterson: Regional-scale relationship among

biological soil crusts, invasive annual grasses, and disturbance. Ecological Processes 2013 2:2.

\section{Submit your manuscript to a SpringerOpen ${ }^{\circ}$ journal and benefit from:}

- Convenient online submission

- Rigorous peer review

- Immediate publication on acceptance

- Open access: articles freely available online

- High visibility within the field

- Retaining the copyright to your article 